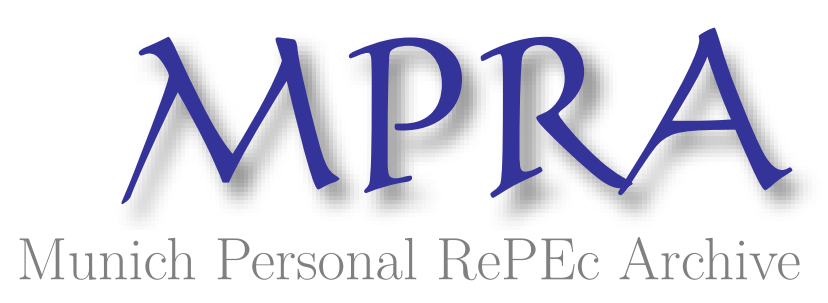

\title{
Examining the level of competition in the energy sector
}

Halkos, George

Department of Economics, University of Thessaly

January 2020

Online at https://mpra.ub.uni-muenchen.de/98343/

MPRA Paper No. 98343, posted 27 Jan 2020 19:09 UTC 


\title{
Examining the level of competition in the energy sector
}

\author{
George Halkos \\ Laboratory of Operations Research, \\ Department of Economics, University of Thessaly
}

\begin{abstract}
During the last decades energy sector has undergone thoughtful structural changes, getting towards a more competitive environment, a process that it is highly controlled and monitored by regulatory authorities. The differences in the pace and extent of market reforms are mainly related to the starting point of each reform and the problems associated with the internal environment of the market. The applied theoretical and analytical contributions provide guidance to policy-makers and government officials in designing new policy scenarios for the investigation of the role of competition in the energy sectors. The empirical contributions provide evidence to support and inform current policy debates and should be of benefit to policy-makers and researchers worldwide.
\end{abstract}

Keywords: Energy sector; competition; liberalization; energy market legislation. 


\section{Introduction}

Energy policy is an emerging and very intense topic in the field of environmental and economic research. A major issue that arises in many recent studies is that of competition in the energy sector. Until the 90s, the energy sector (electricity, natural gas, oil) in most of the European Union (EU) countries was vertically integrated and state-owned. In relation to the situation in Europe, there are still concerns regarding the competition of EU member countries especially about natural gas, whereas the reserves are concentrated and the number of suppliers are limited (Hulshof et al., 2016).

Competition policy is rather complex therefore the associated law and regulations too; much has been written regarding law and economics but not regarding the overall policy assessment (Wilks, 2010). Energy law scholarship demands interdisciplinary insights. The complexities of the interaction between different energy sources and the relevant decision making have been studied by many researchers such as Heffron and Talus (2016).

Energy law, a still quite new area of law is an emerging topic nowadays and includes governing energy-related matters and the management of energy resources (Heffron, 2015). Some important topics of energy law include: market liberalization, environmental issues, climate change, antitrust and state aid rules (Samkharadze, 2019). Policy makers have to suggest policies that reduce greenhouse gas emissions and increase energy security. ${ }^{1}$ According to Brown and Huntington (2008) the optimal policy is performed when the cost of the additional use of each method is equivalent to the value of additional energy security and the resulting reduction in greenhouse gas emissions.

Almost two decades since the opening of the European electricity and gas markets to competition and despite the obvious delays and malfunctions in the European Commission's strategic plan for energy, there are some encouraging signs that the energy market is slowly but steadily moving towards market integration and

\footnotetext{
${ }^{1}$ For policy implications on climate change see among others Halkos and Paizanos (2016), Halkos et al. (2018), for institutions see Evangelinos and Halkos (2002) and Halkos and Evangelinos (2002), for environmental behaviour Gkargkavouzi et al. (2019) and for optimization and pollution control see Halkos (1995, 1996, 2003). For issues in Econometrics see Halkos (2006, 2007, 2019).
} 
liberalization. Latest evidence show market coupling and price convergence for a series of major power markets and gas hubs especially in the North Western European region, with consumers having a variety of available providers to choose from, hence a high percentage of switching rates and an increasing number of market offers.

Specifically, in 2017 almost 6 million household electricity consumers and more than 5.5 million household gas consumers made use of a market offer (Council of European Energy Regulators, 2018). Tulloch et al. (2018) further confirm the increase in European energy market competition, as they discovered a continuous declining trend in the electricity and gas utilities' returns for over a 17 year period, suggesting that the markets are becoming more competitive. Similarly, concerning the USA and according to Brown (2017) from the mid-1990s to early 2009 the U.S. natural gas prices were quite similar to world oil prices but they are a lot lower since 2009 due to technological change that was considerably greater than before the supply of U.S. shale gas resources.

Here we concentrate in the issue of competition in the energy sector paying attention to competition and innovation, energy law and the role of Asian markets in the energy mix and energy security. In the next section we discuss the issue of liberalization in the energy sector while in the third section we consider the main issues around competition. The last section concludes the paper concentrating in the studies of the special issue and their main findings that will assist researchers and policy makers.

\section{Energy sector liberalization}

Competition enhances consumer welfare and ensures the allocation of resources efficiently (Kroes, 2005). According to Painuly (2001) the term energy sector liberalization includes measures aiming at the restructuring of the energy sector, the introduction of competition and the removal of other controls. These measures include among others the following:

- Creation of separate entities for generation and distribution in the electricity sector.

- Entry of private sector companies.

- Removal of controls on energy pricing, fuel use, fuel import, capacity expansion etc. 
- Institutional measures such as specialized regulatory bodies.

Even though these regulations are in place, markets are mainly national with few cross-border trade, therefore the EU Commission has paid great attention into controlling potential mergers (such as the proposed merger between EDP and GDP in Portugal), into setting up rules for mergers and in controlling state aid to energy companies across the EU (European Commission, 2012). The efficacy of those regulations and mechanisms is hindered by conflicts between different national jurisdictions and sector interests (Eberlein, 2008). In more detail, it is necessary to have a common EU competition policy, mainly to achieve low prices for all, better quality, more choice, innovation (in product design, production techniques, services) and better competition potential in global markets (European Commission, 2015).

Therefore it is essential to integrate national markets into a single European one; such an integration depends highly on the physical infrastructure available that can be used (Spiridonova, 2016). In many EU countries infrastructure for energy and gas is still owned by vertically integrated operations and while competition is possible in the extraction and generation stages, it is not easily done at the transmission and distribution parts due to the existing monopolies (Nowak, 2010). Vertically integrated operations create many obstacles to potential competitors which include among others (Jones, 2004):

- Setting technical barriers for instance by having expensive procedures for customers who want to change suppliers.

- Market manipulation through access to private information such as contract tariffs.

- Limiting the available lines so that competitors cannot enter the market.

- Through accounting techniques, they use subsidies in transmission/distribution stages initially directed to generation.

A single market would be one of the possible solutions for securing energy systems and enjoying the benefits of competition for investment and industrial competitiveness (European Commission, 2010). The energy transition in the EU will be hindered if unfair competition is in place and Member States continue to provide fossil fuel subsidies and tax reliefs for certain companies (European Commission, 2017). 
Nevertheless, ideological differences between the governments of the member states combined with severe economic inequality resulted in a less integrated and decelerated European energy market, with multiple trading markets arising in many regions operating under different trading rules and market conditions. Obviously energy market competition and concentration are prominent issues and this may be revealed by the way firms compensate their dedicated employees in such efforts.

Michaelides et al. (2019) consider the effect of market competition on CEO compensation analyzing a sample of American firms of the energy sector for the time period 1992-2015. Market competition is measured by means of the HerfindhalHirschman-Index and industries are divided into small, medium and high market concentration while the effect of the recent financial crisis is taken into consideration. CEOs' salaries are affected by firm-level factors like firm size, financial indexes like ROA and ROE, market concentration, Tobin's Q but also individual characteristics of each CEO such as age, gender, etc. They find a negative and statistically significant impact of market concentration index in the US energy sector on CEO compensation for firms operating in either a monopolistic or a purely competitive environment.

\section{Main issues arising around competition in the energy sector}

As mentioned some current issues around competition in the energy sector are going to be considered like innovation, energy law and the role of Asian markets.

\subsection{Competition and innovation}

Innovation in the energy sector is quite different in relation to other sectors of the economy due to market failures, as indivisibility, spillover effects and uncertainty are more noticeable here (Jamasb and Pollitt, 2008; Costa-Campi et al., 2015). Moreover the fact that the energy sector is highly linked to the environment, explains why greater positive externalities are noticed as well (Salies, 2010; Kim et al., 2012).

There are two main categories for policies related to the R\&D sector (Fabrizio et al., 2017):

- Supply-push: aiming to increase the supply of a particular technology including subsidies, tax credits and financial support for personnel.

- Demand-pull: includes instructed purchases, minimum purchases requirements and targeted subsidies. 
Fabrizio et al. (2017) examine the impact of these two policies on domestic innovation and foreign-invented technologies and conclude that the transfer of those technologies increase with demand-pull policies. In addition considering a dynamic innovation on the European energy industry, it is found that feed in tariffs and certificate markets should be used as complementary regulatory instruments from the production to consumption stages (Midttun and Gautesen, 2007). Moreover the stages of the product cycle should be taken into account regarding policy/regulatory design and create different instruments at each stage to achieve greater results (Midttun and Gautesen, 2007). In relation to that Hulshof et al. (2016) identify that effective policy measures are affected by the capacity allocation mechanisms and investments in cross-border capacity. Finally, Balke and Brown (2018) model U.S. and rest of world oil demand and production estimating the elasticity of U.S. GDP to oil price changes due to oil supply shock. They conclude that reduced U.S. oil use lowers the sensitivity of GDP to oil supply shocks.

In connection with the above, energy demand could be regulated for instance through energy labelling, specific product standards and emission reduction measures, but this area faces many difficulties mainly due to lack of coordination (Cairney et al., 2019). Overall lack of competition in the energy supply market, leads to consumers paying a higher price for their energy use. The average energy bill in the UK has risen dramatically in 2010 compared to 2004 levels. With more competition profit and operations' costs of energy suppliers are kept as low as possible when considering the average consumer bill (Platt, 2012).

Policy makers should actively encourage a broader 'ecosystem' of businesses in emerging energy sectors such as energy services, renewable generation, smart grids and metering which will enable them to create more efficient and competitive markets for the benefit of consumers while creating the potential for innovation and industrial growth (Platt, 2012).

The main drivers affecting policy adoption include: policy characteristics, environmental conditions, economic resources and political constraints and opportunities; above all factors politics and political culture play a bigger part regarding energy and climate change policies (Brown and Huntington, 2008; 
Matisoff and Edwards, 2014). Moreover the role and interaction of user and producer knowledge seems to be highly relevant in this field.

Cheng et al. (2019) analyze the determinants of changes in electricity generation intensity in China revealing the reasons for the differentiations in electricity generation intensity in thermal and sustainable power sectors. They show that changes in electricity generation intensity are attributed to five effects: the role of generation structure, generation-to-consumption ratio and production consumption, residential consumption and consumption loss intensities. Electricity consumption intensity effect dominates the other effects. The impact of production electricity consumption intensity in thermal power sector surpasses its effect in sustainable power sector and the differences between changes in electricity generation intensity in these sectors are mainly due to differences in production electricity consumption intensity with the search for innovation being emerging.

In a dynamic framework, Kyritsis and Andersson (2019) explore the relationships between crude oil price returns and various energy price returns (diesel, gasoline, heating, and natural gas). Using Granger non-causality tests for US spot closing prices from January 1997 to December 2017 they concentrate on different ranges of the full conditional distribution of a dynamic quantile regression model recognizing the quantile ranges where causality arises. This leads to interesting onedirectional dynamic relations between employed energy prices, but also a bidirectional causal relation between energy prices for which empirical findings suggests otherwise.

Heiskanen and Lovio (2010) apply interaction frameworks in Finland to examine such case and find that user involvement can accelerate the acceptance of low-energy solutions according to specific methods for every industry. An important low-energy solution regarding innovation and competition has to do with renewable energy. Charakopoulos et al. (2019) consider wind power as an important element with progressively more contribution in developing economies and many environmental benefits. As wind power is substantially dependent on wind velocity the identification of patterns in wind velocity is a main concern for the renewable energy market. The dynamic characteristics and patterns are explored relying on Recurrence Plots (RPs) and Complex Network analysis. In this way useful 
information may be provide in such analyses which can identify and discover dynamical transitions in the system's behaviour revealing information about changes and predicting the produced wind energy helping wind site assessment selection.

The spatial planning optimization to identify suitable locations for installing wind farms is a very serious and difficult problem due to the requirement of identifying various qualitative and quantitative parameters. Ioannou et al. (2019) incorporate the social factors affecting wind farm investments and propose a methodology easily modifiable and replicable by researchers with the ability to create and study scenarios. At the same time there is capability to adjust the resolution and the accuracy of the location selection. Specifically, a methodology which combines a Multi Criteria Decision Making Methods (MCDM) methodology called Analytical Hierarch Process (AHP) and Geographic Information Systems (GIS) to establish suitable places for installing wind farms. Planned locations are ranked on installation suitability using the Technique for Order Preference by Similarity to Ideal Solution (TOPSIS). This proposed methodology may assist decision makers to cope with conflicting parameters recommending the most favourable economical and environmental friendly solutions acceptable by citizens and stakeholders.

Initially competition measures may not be in favour of renewable energy but in the longterm these measures would provide a healthier growth to renewables (Painuly, 2001). Johnstone et al. (2010) conducted a panel data analysis for 25 countries for the period 1978-2003 and identify that diverse policy instruments may prove effective for different renewable sources with tradeable energy certificates more likely to bring on innovation.

Subsidies such as feed-in-tarriffs may prove valuable for more costly renewable sources such as solar power (Johnstone et al., 2010). In addition to that Nicolli and Vona (2019) identify that energy liberalization increases public support for renewable energy and also a reduction in the monopolistic power of state-owned utilities has a positive effect on renewable energy policies. Overall more competition would reduce the financial burden of renewable schemes and help achieve the set renewables' use targets (Szabó and Jäger-Waldau, 2008).

In relation to innovation in the sector, smart grids are widely promoted in the EU and worldwide. These can be defined twofold, first they are defined as "electricity 
networks that can intelligently integrate the behaviour and actions of all users connected to it - generators, consumers and those that do both - in order to efficiently deliver sustainable, economic and secure electricity supplies" (Clastres, 2011). Another definition is that a smart grid must integrate the characteristics or deliver the performance described below: "self-healing from power disturbance events; enabling active participation by consumers in demand response; operating resiliently against physical and cyber-attack; providing power quality for $21^{\text {st }}$ century needs; accommodating all generation and storage options; enabling new products, services, and markets; optimizing assets and operating efficiently" (Clastres, 2011).

With smart grids Member States can achieve targets in relation to the promotion of competition, safety of energy systems and combating climate change. Real-time data that will be provided by smart grids will create new market conditions for generators and consumers. Many European countries (France, Ireland, the Netherlands, Spain and the UK) have established firm targets for smart grid development (Clastres, 2011). It is forecasted that smart grids will be deployed nationwide by 2020 (Faruqui et al., 2010).

\subsection{Developments in the European energy market legislation}

There are several motives for developed economies globally to proceed to structural reforms and liberalization of their energy markets. Such strategic decisions are mainly driven by economic incentives and the rising benefits from the introduction of market competition, however there could also be geopolitical and environmental reasons that lead governments towards structural changes of their energy market policies. Specifically, in the case of the European Union the implemented energy market reform has a broader perspective and meaning than simple economic concerns, as it is part of the general strategic planning for real political and market unification of the participating member states.

In general, the opening of energy market to competition requires several key measures that aim to restructure the supply conditions of specific energy sectors such as electricity and gas increasing competition, while it often includes the establishment of an independent regulatory authority. The purpose of such policy changes lies in the fact that competition enhances innovation and cost efficiency leading price reduction for both household and industrial consumers. State energy models in the European 
region involving national monopolies or oligopolies, as well as limited market coupling, network connectivity and price convergence made urgent for the European commission to act and develop a paneuropean energy policy that would reverse these dominating trends within the union.

In an attempt to deal with all the above energy market deficiencies the European Commission developed a strategic policy for a unified European energy market. The concept of an internal energy market was established in order to drive the process towards a single electricity and gas market free of restraints that would activate European power and gas firms to expand into several member countries boosting competition and create a better market environment that would attract foreign investments.

Specifically, during the past few decades the European Commission put a great deal of effort through establishing the appropriate legal framework and policies to promote diversification and flexibility in the European energy market. The EU has enhanced its energy laws with greater extraterritorial power in order to improve its relations with neighbouring regions (Samkharadze, 2019). Article 194 of the Treaty on Functioning of the European Union (TFEU) outlines the key EU energy policy objectives under three main policy principles: competitiveness, security of supply and sustainability. In addition the EU has bilateral agreements with third countries (i.e., Free Trade Agreements, Partnership and Cooperation Agreements, Association Agreements) (Samkharadze, 2019).

Specifically, the EU has focused on its competition policy with the first liberalization directives established in 1996 (electricity) and 1998 (gas) and the second liberalization directives adopted in 2003 (European Commission, 2012). These policies make sure that companies having a fair competition, provide more choices to consumers and reduce prices while improving their offered quality (European Commission, 2015).

Moreover in 2009 the 'third liberalisation package' was established in the EU with stricter regulations on unbundling and the development of new authorities as well. Simultaneously the EU Commission investigates breaches of EC Competition law. Under this regulation, Member States have to choose between three unbundling regimes which include Full Ownership Unbundling, Independent System Operator (ISO) and Independent Transmission Operator (ITO); the Commission has a 
preference for Full Ownership Unbundling as the standard model for guaranteeing the independence of network operators (Scholz and Purps, 2010).

The two first sets of Directives regarding the electricity and gas markets respectively, concentrated in unbundling these two energy sectors and gradual open national markets to competition. Particularly the second package of Directives in 2003 were designed to accomplish the unbundling of transmission and distribution network operators from the rest of the industry, the free market entrance of new providers, as well as the continuous monitoring of the supply competition level with further encouragement of renewable energy sources and reinforcement of the role of regulators. Additionally, the third package was endorsed to achieve the goal of a unified and functional European energy in which consumers will be enabled to benefit from the variety of available providers and the reduced prices. The implementation of the third legislative package was expected to intensify competition and strengthen market transparency and consumer protection rules.

The development and execution of this strategic plan for energy by the European Union was from the beginning a rather challenging and ambitious task unique in terms of its scale. Jamasb and Pollit (2005) support that the European energy market liberalization and unification process constitutes the world's most extensive cross-jurisdiction reform of the kind especially regarding electricity.

According to Brown and Huntington (2017) OPEC's market power enlarges its share of the marginal barrel of oil and a reduction of world consumption boosts world oil security with rising non-OPEC sources of oil augmenting world oil security. Szőke et al. (2019) compare the market power of Hungarian electricity traders initially in the partially liberalised transitional market model from 2004 to 2008 and then for the fully liberalised period since 2008. They propose the use of an econometric modelling technique relying on asymmetric price transmission (APT) theory for analysing the competition on electricity markets. In this way they measure the market power of traders in the electricity market with the asymmetric price transmission assumption referring to deviations from perfect competition. It is shown that different regulation regimes lead to different asymmetry patterns in price transmission underlining that electricity traders have improved their position since the introduction of the liberalised market model. 
This modernized and more liberal energy market offered energy providers across the European Union the opportunity to negotiate their energy sale contracts under better conditions and with an increased competitiveness, due to a variety of available options relative to supply routes and the access to millions of households and businesses around the globe.

Nguyen et al. (2019) explore energy transition, energy poverty and energy inequality in Vietnam using data on residential energy expenditure of more than 9,000 households for 2004 - 2016. They realize a transition from traditional to modern energy which varies across regions and among ethnic and welfare groups and rural and urban population. Electricity poverty has been reduced while energy-cost poverty has increased and there is a trend for energy inequality to be reduced at a higher rate compared to income and consumption inequalities. This is justified as they suggest a national program to alleviate energy poverty by setting up policies to lower households' energy costs and helping poor and ethnic minority households to have enough money for access to the necessary electricity consumption.

Similarly, Athukorala et al. (2019) consider residential demand for electricity in Sri Lanka using survey data for 2011 and 2015. They realize that the main demand determinants for residential electricity are the outcome of price or market distortions (i.e. subsidies), various socioeconomic variables and energy saving technology. The consequences of these variables are predominantly related to competition policy. Various elasticities with respect to average price, subsidies under marginal cost pricing, subsidies under average cost pricing and income are calculated showing that electricity demand is inelastic and categorised as normal good. But elasticities with respect to subsidy variables are found higher than the price variable implying that under an increasing block rate system any applied price change to control electricity consumption will be ineffective. This is justified as price changes could modify received subsidies by consumers and overturn the objective of price change. Even more, they find that price and elasticities for subsidy variables are comparatively superior for low income groups while income elasticity is reasonably larger for high income groups. 


\subsection{The role of Asian markets}

Asian markets have been driving the trends in world energy markets, whereas the gap between consumption and production levels in Asia expands, thus creating energy insecurity and hindering economic growth (Chanlett-Avery, 2008). China's growth as an energy consumer is quite spectacular as in 2003, it surpassed Japan to become the world's second largest oil consumer after the United States (US) and is now the world's fifth largest importer of oil (Tow, 2007). China has implemented a state-centered approach towards energy security and massively invested in oil fields and pipelines worldwide (Zhao, 2008). The country's need to diversify has created closer relationships with Central Asia, the Middle East and the oil producing countries of Africa and Latin America (Kenny, 2010).

Regarding its relationships with other neighbouring countries, with some new opportunity for cooperation have arisen, while with others conflicts have occurred (i.e. regarding maritime territories) (Zhao, 2008; Kenny, 2010). These trends undoubtedly affect US and EU policy. The price variations due to China's increasing demand may create power struggle to secure access to energy resources (ChanlettAvery, 2008). Moreover energy cooperation in Northeast Asia has become essential for energy supplies and preventing potential conflicts, focusing more on the aspect of public goods (Lee, 2010).

What is more Russia's relationship with the rest of the world and especially neighbouring countries needs to be taken into account. As it stands there is a clear asymmetry in the relationship between the EU, US and Russia with national monopoly on the supply side (Russia) and open competitive markets on the other. Europe is inevitably dependent on Russia for gas but this dependence is not enough to succumb to monopolistic approaches (Milov, 2006). Overall Russia has the ability to move fast in establishing bilateral energy agreements in countries such as Croatia, Serbia and Bulgaria which in turn creates obstacles to US efforts to promote EU import diversity and challenge Russia's influence in Eastern European countries especially (Smith, 2010).

EU and US also collaborate with each other especially for gas imports from Ukraine (70\% of Europe's gas originating from there) to avoid a pipeline shutoff of gas to Europe from Russia; so far though little has been achieved mainly due to 
Ukraine's economic and political situation (Smith, 2010). Stronger enforcement of EU competition rules will bring on changes in Russia too as the expansion of companies like Gazprom will be limited and monopolies will disappear; at the same time downstream mergers and acquisitions, mostly desired by Russia, will decrease (Milov, 2006).

In these lines, Talipova et al. (2019) examine the dramatically changing competition landscape of the Russian natural gas industry highlighting the risks for independent gas producers associated with replacing price floor with gas exchange benchmark. With high EU prices, the state-owned monopolist Gazprom lost half of the domestic market but the situation changed in 2014 with oil price reduction and Gazprom renewed its interest to domestic market having its lowest bid price regulated. Having other producers offering discounts since September 2014 gas exchange is promoted by the Federal Antimonopoly Service (FAS) as efficient market and valuable part of deregulation strategy. In 2016 FAS recommended to drop minimum selling price for Gazprom in July 2019, aiming primarily to competition and consumer protection.

\section{Conclusion}

An essential criterion for the development of a liberalized and competitive energy market is to make sure that both the industrial and household sectors are fully liberalized and open to market competition. Consequently this will create competition between energy providers and encourage consumers to demand better pricing. The European Union's strategic plan for an internal energy market and the legal framework that was created to develop the necessary market conditions to promote this vision definitely laid the foundation towards a unified and more competitive European energy market. Nevertheless, the insufficient market reform combined with the slow implementation of the three fundamental Directive packages by the European member states, may further delay reaching the target of a unified and competitive energy market much more than the end of this decade.

In order to create a functional energy market and to enhance competition and innovation, any market entry barriers and price controls must be removed. Additionally, competitive energy markets also require the active participation of consumers. This is primarily expressed by the consumers switching rate, which mainly relies on the level of difficulty of the switching process, the market 
information availability, as well as the legal rights and the established mechanisms that could motivate consumers to become more active. Consumer engagement puts pressure on energy providers and it is a very representative indicator for the competitive level in an energy market.

In this special issue various findings emerge:

- A statistically significant negative effect of market concentration exist in the case of the US energy sector on CEO compensation for competitive or monopolistic firms.

- Different regulation regimes result to different asymmetry patterns in price transmission

- The impact of production electricity consumption intensity in thermal power sector surpasses its effect in sustainable power sector with differences between changes in electricity generation intensity due to differences in production electricity consumption intensity

- The main demand determinants for residential electricity predominantly related to competition policy are the result of price or market distortions (in the form of subsidies), various socioeconomic variables and energy saving technology.

- National programs are proposed to lighten energy poverty setting up policies to lower households' energy costs and helping poor and ethnic minority households in their necessary electricity consumption

- For the relationships between crude oil price and various energy price returns onedirectional dynamic relation between employed energy prices is fount, but on the contrary a bi-directional causal relation exists between energy prices.

- In Russia and for its monopolistic energy firm (Gazprom) a drop in the minimum selling price in July 2019 is recommended, aiming primarily to competition and consumer protection.

Finally, to help policy makers to identify dynamic characteristics and patterns Recurrence Plots (RPs) and Complex Network analysis may identify and discover dynamical transitions in the system's behaviour revealing information about changes and predicting the produced wind energy helping wind site assessment selection. Similarly combining a Multi Criteria Decision Making Methods (MCDM) methodology called Analytical Hierarch Process (AHP) and Geographic Information Systems (GIS) may found suitable places for installing wind farms to dealing with conflicting parameters and recommending the most favourable solutions socially and economically. 


\section{References}

Balke N.S. and Brown Stephen P.A. (2018). Oil Supply Shocks and the U.S. Economy: An Estimated DSGE Model, Energy Policy, 116: 357-372.

Brown Stephen P.A. (2017). Natural gas vs. oil in U.S. transportation: Will prices confer an advantage to natural gas?," Energy Policy, 110(C): 210-221.

Brown Stephen P.A. and Huntington H.G. (2017). OPEC and World Oil Security. Energy Policy, 108: 512-523.

Brown Stephen P.A. and Huntington H.G. (2008). Energy Security and Climate Change Protection: Complementarity or Tradeoff? Energy Policy, 36(9): 3510-3513.

Cairney, P., McHarg, A., McEwen, N. and Turner, K. (2019) How to conceptualise energy law and policy for an interdisciplinary audience: The case of postBrexit UK. Energy Policy, 129, 459-466.

Chanlett-Avery, E. (2008) Rising Energy Competition and Energy Security in Northeast Asia: Issues for U.S. Policy. CRS Report for Congress, Order Code RL32466.

Clastres, C. (2011) Smart grids: Another step towards competition, energy security and climate change objectives. Energy Policy, 39(9), 5399-5408.

Costa-Campi, M.T., Garcia-Quevedo, J. and Trujillo-Baute, E. (2015) Challenges for R\&D and innovation in energy. Energy Policy, 83, 193-196.

Council of European Energy Regulators (2018). Performance of European Retail Markets in 2017. CEER Monitoring Report. Brussels, Belgium. Retrieved from: https://www.ceer.eu/documents/104400/-/-/31863077-08ab-d166-b611$2 \mathrm{~d} 862 \mathrm{~b} 039 \mathrm{~d} 79$

Eberlein, B. (2008) The Making of the European Energy Market: The Interplay of Governance and Government. Journal of Public Policy, 28(1), 73-92.

European Commission (2010) Europe 2020 initiative - energy infrastructure priorities for 2020 and beyond: a blueprint for an integrated European energy network. Available at: https://climate-adapt.eea.europa.eu/metadata/publications/energyinfrastructure-priorities-for-2020-and-beyond-a-blueprint-for-an-integratedeuropean-energy-network

European Commission (2012) Energy and environment - Overview. Available at: http://ec.europa.eu/competition/sectors/energy/overview en.html

European Commission (2015) Overview: making markets work better. Available at: http://ec.europa.eu/competition/general/overview en.html

European Commission (2017) The Committee of the Regions and the European Investment Bank. Third Report on the State of the Energy Union. Communication from the Commission to the European Parliament, The Council, The European Economic and Social Committee, The Committee of the Regions and the European Investment Bank, COM(2017) 688 final.

Evangelinos K. and Halkos G. (2002). Implementation of environmental management systems standards: important factors in corporate decision making. Journal of Environmental Assessment Policy and Management 4(3): 311-328. 
Fabrizio, K.R., Poczter, S. and Zelner, B.A. (2017) Does innovation policy attract international competition? Evidence from energy storage. Research Policy, 46(6), 1106-1117.

Faruqui, A., Harris, D. and Hledik, R. (2010) Unlocking the $€ 53$ billion savings from smart meters in the EU: how increasing the adoption of dynamic tariffs could make or break the EU's smart grid investment. Energy Policy, 38, 6222-6231.

Gkargkavouzi A., Halkos G. and Matsiori S. (2019). Environmental behavior in a private-sphere context: Integrating theories of planned behavior and value belief norm, self-identity and habit. Resources, Conservation and Recycling 148: $145-156$.

Halkos G. (1995). Evaluation of the direct cost of sulfur abatement under the main desulfurization technologies. Energy sources 17(4): 391-412.

Halkos G. (1996). Incomplete information in the acid rain game. Empirica 23 (2): 129-148.

Halkos G. and Evangelinos K. (2002). Determinants of environmental management systems standards implementation: evidence from Greek industry. Business Strategy and the Environment 11(6): 360-375.

Halkos G. (2003). Environmental Kuznets Curve for sulfur: evidence using GMM estimation and random coefficient panel data models. Environment and Development Economics 8(4): 581-601.

Halkos G. (2006). Econometrics: Theory and practice. Giourdas Publications

Halkos G. (2007). Econometrics: Theory and Practice: Instructions in using Eviews, Minitab, SPSS and Excel. Gutenberg: Athens, Greece.

Halkos G. (2019). Econometrics: Theory and practice. 2nd Edition. DISIGMA.

Halkos G. and Paizanos E. (2016). The effects of fiscal policy on CO2 emissions: Evidence from the USA. Energy Policy 88: 317-328.

Halkos G., Skouloudis A., Malesios C. and Evangelinos K. (2018). Bouncing back from extreme weather events: Some preliminary findings on resilience barriers facing small and medium-sized enterprises. Business Strategy and the Environment 27(4): 547-559.

Heffron, R. J. (2015) Energy Law: an Introduction. Springer.

Heffron, R.J. and Talus, K. (2016) The development of energy law in the $21^{\text {st }}$ century: a paradigm shift. Journal of World Energy Law and Business, 9(3), 189-202.

Heiskanen, E. and Lovio, R. (2010), User-Producer Interaction in Housing Energy Innovations. Journal of Industrial Ecology, 14, 91-102.

Hulshof, D, van der Maat, J.-P. and Mulder, M. (2016) Market fundamentals, competition and natural-gas prices. Energy Policy, 94, 480-491. 
Jamasb T. and Pollitt M. (2005). Electricity Market Reform in the European Union: Review of Progress toward Liberalization and Integration. The Energy Journal, 26, pp. 11-41.

Jamasb, T. and Pollitt, M.G. (2015) Why and how to subsidise energy R+D: Lessons from the collapse and recovery of electricity innovation in the UK. Energy Policy, 83, 197-205.

Johnstone, N., Haščič, I. and Popp, D. (2010) Renewable Energy Policies and Technological Innovation: Evidence Based on Patent Counts. Environmental and Resource Economics, 45(1), 133-155.

Jones, Ch.W. (2004) EU Energy Law. Volume 1-The Internal Energy Market. Claeys $\&$ Casteels, Leueven.

Kenny, H.J. (2010) China and the competition for oil and gas in Asia. Asia-Pacific Review, 11(2), 36-47.

Kim, J., Kim, Y. and Flacher, D. (2012) R\&D investment of electricity-generating firms following industry restructuring. Energy Policy, 48, 103-117.

Kroes, N. (2005) European Competition Policy - Delivering Better Markets and Better Choices. European Consumer and Competition Day, London, UK.

Matisoff, D.C. and Edwards, J. (2014) Kindred spirits or intergovernmental competition? The innovation and diffusion of energy policies in the American states (1990-2008). Environmental Politics, 23(5), 795-817.

Midttun, A. and Gautesen, K. (2007) Feed in or certificates, competition or complementarity? Combining a static efficiency and a dynamic innovation perspective on the greening of the energy industry. Energy Policy, 35(3), 1419-1422.

Milov, V. (2006) The EU-Russia Energy Dialogue: Competition Versus Monopolies. IFRI Research Programme Russia/NIS.

Nicolli, F. and Vona, F. (2019) Energy market liberalization and renewable energy policies in OECD countries. Energy Policy, 128, 853-867.

Nowak, B. (2010) Equal access to the energy infrastructure as a precondition to promote competition in the energy market. The case of European Union. Energy Policy, 38(7), 3691-3700.

Painuly, J.P. (2001) Barriers to renewable energy penetration; a framework for analysis. Renewable Energy, 24(1), 73-89.

Platt, S. (2012) The True Cost of Energy. Institute for Public Policy Research.

Salies, E. (2010) A test of the Schumpeterian hypothesis in a panel of European Electric Utilities. J.L. Gaffard, E. Salies (Eds.), Innovation, Economic Growth and the Firm, Edward Elgar Publishing, US.

Samkharadze, I. (2019) Europeanization of energy law and policy beyond the Member States: The case of Georgia. Energy Policy, 130, 1-6.

Scholz, U. and Purps, S. (2010) The Application of EC Competition Law in the Energy Sector. Journal of European Competition Law \& Practice, 1(1), 3751. 
Smith, K.C. (2010) Russia-Europe Energy Relations: Implications for U.S. Policy. Center for Strategic and International Studies, Washington D.C.

Spiridonova, O. (2016) Transmission capacities and competition in Western European electricity. Energy Policy, 96, 260-273.

Szabó, S. and Jäger-Waldau, A. (2008) More competition: Threat or chance for financing renewable electricity?. Energy Policy, 36(4), 1436-1447.

Tow, W.T. (2007) Strategic dimensions of energy competition in Asia. In: Energy Security in Asia, Michael Wesley (Ed.), Routledge, Oxon.

Tulloch D.J., Diaz-Rainey D. and Premachandra I.M. (2018). The impact of regulatory change on EU energy utility returns: the three liberalization packages. Applied Economics 50(9): 957-972

Wilks, S. (2010) Competition Policy. The Oxford Handbook of Business and Government, Edited by David Coen, Wyn Grant and Graham Wilson.

Zhao, S. (2008) China's Global Search for Energy Security: cooperation and competition in Asia-Pacific. Journal of Contemporary China, 17(55), 207227.

\section{Special Issue's accepted papers}

Athukorala W., Wilson C., Managi S. and Karunarathna M. (2019). Household demand for electricity: the role of market distortions and prices in competition policy. Energy Policy

Cheng S., Wu Y., Chen H., Chen J., Song M. and Hou W (2019). Determinants of changes in electricity generation intensity among different power sectors. Energy Policy

Charakopoulos A., Karakasidis T. and Sarris I. (2019). Pattern identification for wind power forecasting via Complex Network and Recurrence plot time series analysis. Energy Policy

Ioannou K., Tsantopoulos G. and Arabatzis G. (2019). A Decision Support System methodology for selecting wind farm installation locations using AHP and TOPSIS: Case study in Eastern Macedonia and Thrace region, Greece. Energy Policy

Kyritsis E. and Andersson J. (2019). Causality in Quantiles and Dynamic Relations in Energy Markets. Energy Policy

Michaelides P., Tsionas E., Konstantakis K. and Xidonas P. (2019). The impact of market competition on CEO salary in the US energy sector. Energy Policy

Nguyen Trung T., Nguyen Thanh T., Hoang V.N., Wilson C. and Managi S. (2019). Energy transition, poverty and inequality in Vietnam. Energy Policy

Szőke T., Balogh E. and Hortay O. (2019).Asymmetric Price Transmission in the Hungarian Retail Electricity Market. Energy Policy

Talipova A., Parsegov S.G. and Tukpetov P. (2019). Russian Gas Exchange: a New Indicator of Market Efficiency and Competition or the Instrument of Monopolist? Energy Policy 